\title{
Ethical Dilemmas Arising from the Implications of Military and Medical Professions in Military Medicine
}

\section{Askeri Tipta, Askerlilk ve Tip Mesleklerinin Etkillerinden Ortaya Çıkan Etik İkilemler}

\author{
Eray Serdar YURDAKUL ${ }^{a}$
}

\begin{abstract}
When the profession groups are examined, we can talk about medicine and military service as two professions whose history are as old as human history. These two professions, which are inherently essential for making sacrifices for others, have been in constant interaction throughout history. While military service always has the potential to threaten human life and health, medical concepts such as injured treatment are the most needed professions. Medicine always aims to protect human life and health. Undoubtedly, the expectation of the society from the physician is to improve the conditions of illness and injury and to protect the health. In fact, the principle of not to give harm and benefit is the basis of medical ethics. On the contrary, the expectation of the society from the military profession group is to show an effect if necessary for the purpose of providing national security. In our study; dilemmas such as whether a physician providing health services to soldiers acts contrary to the nature of the medical profession by maintaining a destructive force will be examined. Methods: In the study, concepts related to the subject such as morality, ethics, types of ethics, applied ethics, medical ethics, deontology, and ethical dilemma were examined first. Since ethical dilemmas related to military medicine in particular will be examined, the legal regulations on this issue have been mentioned. The problems arising from the combined practice of military and medical professions, which are our subjects, have been philosophically discussed with examples from recent Turkish military history. Results: Although many legal and deontological arrangements have been made on the subject, it has been observed that physicians are faced with ethically controversial gray areas while performing their profession within the militaryprofession. Militaryphysician; Thepeople heserves within the hierarchicalstructure he is in, theirrelatives, and the institution that receives the service, face positions other than the classical physician-patient relationship. Discussion and Conclusion: In medical practices to be carried out as a Military Physician, many ethical dilemmas may be encountered due to the behaviors that are specific to the profession, to comply with the determined principles and rules, or to have to comply legally. These ethical dilemmas are not a situation that can only be resolved by questioning the priority of being a soldier or medical doctor. Unfortunately, there isn't any simple answer. Since each case has its own unique feature, a balanced approach can be demonstrated with a comprehensive analysis.
\end{abstract}

Keywords: Military Physician; Ethic Dilemmas; Profession; Soldier

Özet: Meslek grupları incelendiğinde, geçmişi insanlık tarihi kadar eski iki meslek olarak tıp ve askerlikten bahsedebiliriz. Başkaları için fedakarlık yapmak için doğası gereği gerekli olan bu iki meslek, tarih boyunca sürekli etkileşim halindedir. Askerlik; her zaman insan hayatını ve sağlğ̆ın tehdit etme potansiyeline

\footnotetext{
${ }^{a}$ Dr. Öğr. Üyesi, Sağlık Bilimleri Üniversitesi, Gülhane Tıp Fakültesi, Tıp Tarihi ve Etik Ad., Ankara, Türkiye $\bowtie$ erayserdar.yurdakul@sbu.edu.tr Gönderim Tarihi: $17.08 .2020 \bullet$ Kabul Tarihi: 25.10 .2020
} 
sahipken aynı zamanda yaralanma, tedavi gibi tıbbi kavramların en çok iç içe olduğu meslektir. Tip her zaman insan hayatını ve sağlığını korumayı amaçlar. Kuşkusuz toplumun hekimden beklentisi hastalık ve yaralanma koşullarının iyileştirilmesi ve sağlı̆̆ın korunmasıdır. Aslında zarar ve fayda vermeme ilkesi tıp etiğinin temelidir. Aksine, toplumun askerlik mesleğinden beklentisi, milli güvenliğin sağlanması amacıyla etki göstermesidir. Çalısmamızda; askerlere să̆lık hizmeti veren bir hekim, tahrip edici bir gücün devamını sağlayarak tıp mesleğinin doğasına zıt mı hareket etmektedir sorusu gibi ikilemler incelenecektir. Yöntem ve Gereçler: Çalıs̆mada öncelikle ahlak, etik, etik türleri, uygulamalı etik, medical etik, deontoloji, etik ikilem gibi konu ile ilgili kavramlar incelenmiştir. Özelde askeri hekimlik ile ilgili etik ikilemler inceleneceğinden dolayı bu konu ile ilgili yasal mevzuata değinilmiştir. Konumuz olan askerlik ve hekimlik mesleklerinin bir arada icra edilmesinden kaynaklanan problemler yakın tarihten örnekle felsefi olarak tartı̧̧lmıştır. Bulgular: Konu ile ilgili birçok yasal ve deontolojik düzenleme yapılmasına karşın, hekimler askerlik mesleğgi içinde mesleklerini icra ederken etik açıdan tartışmalı gri alanlar ile yüzleştikleri görülmüstür. Askeri hekim; bulunduğu hiyerarşik yapı içinde hizmet verdiği insanlar, onların yakınları, hizmet alan kurum karşısında klasik hekim-hasta ilişkisinin dışında konumlarla yüzleşmektedir. Tartışma ve Sonuç: Askeri Hekim olarak yapılacak tıbbi uygulamalarda askerlik ve hekimlik mesleklerine özgü davranısların çelişmesi, tıp mesleğinin icrası sırasında medical öncelikleri korumaya çalışırken askeri ilke ve kurallara uyulması veya içinde bulunulan statü nedeniyle hukuken uymak zorunda olunması pek çok etik ikilem doğurabilir. Bu etik ikilemler, ancak askerlik veya tıp doktoru olma önceliğinin sorgulanmasıyla çözülebilecek bir durum değildir. Maalesef basit bir çözümü olmayan bu ikilem, her vakanın kendine özgü bir özelliği olduğundan, o vakaya özgü kapsamlı bir analiz ile dengeli bir yaklaşımla yönetilebilir.

Anahtar Kelimeler: Askeri Hekim; Etik İkilemler; Meslek; Asker

\section{INTRODUCTION}

Ethics, which is a discipline for human behavior, creates codes related to that field when it is directed to different occupational groups. When the most indispensable occupational groups are listed in all societies, medicine and military service are undoubtedly at the top. These two professions, which have their own strict principles and function at all times and under all conditions, have been in constant interaction throughout history. While the military profession, by nature, has the potential to threaten human life and health, whether for defense or offensive purposes, medicine always aims to protect human life and health. In this sense, does the word "Military Physician" have a dilemma in itself? With this study, it is aimed to draw attention to the ethical dilemmas of military and medical professions as two different professional fields which being together in military medicine and to raise awareness on ethical decision-making.

In order to evaluate the ethical dilemmas that military physicians experienced in performing their professional activities, the definitions and importance of the concepts of ethics, medical ethics, professional ethics, deontology, ethical assessment and ethical dilemma should be mentioned.

\section{GENERAL CONCEPTS}

Morality and Ethics are known as "Ethics" in English, "Ethos" in Greek, "Ethica" in Latin and "İlm-i Ahlak" in old Turkish. It examines concepts such as good and goodness, right and wrong in human behavior. Is there absolute good and absolute truth? Issues such as how to approach a person, if any, are also included in the field of ethics. It is based on interventions and reasoning actions that have been questioned for many years. 
Ethical problems can be encountered not only among themselves but also in different relationships such as family, society and state, as people who create values in natüre (1-5).

"Morality" ("Ahlak" in Turkish) which is an Arabic word in Turkish, means "creating" (hulk in Arabic) derived from the same root. It is the application of ethics in the philosophical plane at social practice. Morality determines its own specific principles of behavior for each society in the form of rules not written in the community $(1,3,5)$.

In the 70s when Ionna Kuçuradi (Turkish philosopher, academician, president of the Philosophical Society of Turkey) published her book titled Ethics, the subject of ethics was an outdated area, she stated that the issue of ethics was in fashion again in recent years. She states that various factors play a role in this interest. One of these factors is the demand for respect for all cultures and the relativist approach of post-modernism to norm problems - the "anything happens" principle- in response to the upheaval that has created attempts to develop universal ethics in some circles, have been dealt with in the professional practice level. With the concept of professional ethics, not only in theory, but in private, public, professional life, concepts such as virtue, goodness, evil and justice which is the subject of philosophy since the beginning started to be examined on the level of professional practice (6).

Aristotle Nikomakhos divides virtues into two as thoughts and characters in Ethics. He mentions that habits are obtained by repeating character virtues. Character virtues are not found naturally because things that are natural, are not obtained by habit. Consequently, virtue can be gained with a habitual manner in behavior (7). Ethical and virtuous behavior of everyone is a desired situation in social life. In fact, the existence of general ethical rules for everyone, defended by Kant, can be accepted as the desired level in social relations.

Ethics is divided into two as normative and non-normative. Normative ethics: Why and which general valid moral norms are questioned. Non-normative ethics are divided into two as descriptive and metaetical. Descriptive ethics examines how people behave and think in behavior and moral situations. The concept, logic and reasoning in normative ethics with terminology are examined in metaethics. It is determined what behaviors in descriptive and meta ethics are in reality and conceptually. It is not concerned with how it should be morally. With this aspect, it differs from normative ethics (8).

\section{Medical Ethics, Professional Ethics and Deontology}

When it comes to the concepts of medical ethics and professional ethics, medical ethics (medical ethics) seems to be as old as the history of science. Looking at the relationship between physicians and their patients in a historical way, it is seen that they have a historical basis that goes back to Hippocrates. With the oath given, physicians are given a number of ethical assignments and it is stated how to treat their patients (9).

Medical ethics is the case of what health workers do and avoid doing in order to treat the patient well in the awareness of ethical sensitivity in their medical actions. In medical relations, it deals with the medicine-specific values and rules of action (10).

As a result of the popularization and commercialization of health services, the subject of medical ethics remains on the agenda with the change of patient-physician relationship, the meaning of the profession and physician identity and its perception in the society. With the increase of scientific knowledge and technological opportunities, it requires medical education with the emerging problems (11).

In the confusion of the terms "Medical Ethics" and "Medical Deontology", Deontology is used by the term Jeremy Bentham in the first half of the 19th century.

In return for the "Obligations of Information", he states that the obligations determined are compelling and indisputable. The adoption of the term used among physicians for the first time in 1834 refering professional 
legal and moral obligations called as medical deontology. Although deontelogy is identified with medicine firstly, it can be mentioned for every profession (1).

When deontology is mentioned, there is no doubt that the German philosopher Immanuel Kant and the ethics of homework come to mind. Kant universally acknowledges the existence of Moral Law. It is of the view that what ethically important is the intention in action, not success and outcome (12).

The concept of professional ethics can be defined as a prompt for rules that make arrangements for good guidance in profession-specific behaviors, limit the personal wishes of professional members, develop professionspecific norms, and exclude those who do not comply with the established principles and rules (10).

In line with the development of technology, the area of ethics is expanding. Developing scientific and technological innovations, traditional medicine rituals and rules in the patient-physician relationship, brand new value problems and ethical dilemmas are encountered. Medical ethics is the theoretical discipline that examines the principles that determine the attitude and behavior of a physician in situations that force him or her to make choices. In solving professional ethics problems, the question of how to take proper action is one of the most fundamental questions. Of course, questions about ethical and legal norms that will constitute the answers to these questions, are also needed. If the questions such as "what should be done and what should not be done" are clarified, the issues should be discussed and resolved. International declarations, conventions, moral codes and ethical codes are determined by discussing these questions $(13,14)$.

\section{Ethical Evaluation in Ethical Problems, Ethical Dilemma:}

Ethical assessment makes ethical analysis of situations and processes that are experienced or not-experienced. It is to determine which ethical principles and rules related to this situation and processes, in which actual or potential ethical problems exist. Ethical evaluation is constantly experienced in daily medical practices (10).

First of all, it is necessary to observe the behaviors in order to reach an ethical judgment. Human behavior should be defined and evaluated. Then these behaviors must be assessed as principles, rules, norms and moral (15).

Problems related to ethics include the dilemma and the contravention. The dilemma can be defined as the choice problem experienced by the decision maker in cases where the rule is not specified, and the violation can be defined as the violation of professional standard rules. In ethical dilemmas, different principles and rules require each to take a different action, with each being close together. Therefore, acting in accordance with one principle is to act separately from the other (10).

The Turkish meaning which can be explained as pincers situation. The term is also defined by Phylosophy glossary of Turkish Language Council as the situation that offers me to follow two futile ways and forces me to act in one of these ways, even if I do not desire to do so (3).

The dilemma in ethical decision making is defined by Berggren et al. (16) as a logical decision-making process, in a systematic way of thinking, with favor of the most morally correct action in conflicting options. It is important to make an ethical decision with a professional approach by being aware of the ethical problems in the dilemmas encountered at health field (17).

The physician always tries to decide what is best for the patient. The relationship between the patient and the physician may not be easy under some circumstances. In the encountered situations, the physician can often be in serious dilemmas and trying to find a moral solution. The World Medical Association is warned to take care of the patient first, regarding the ethical problems encountered in the Medical Ethics Handbook (18).

Responsible for the protection of Public Health, the physicians treating illness and preventing injury, directly or indirectly, within the armed forces that may cause injury to someone else with "do no harm" policy, could be a question without clear answer for doing the task. 


\section{Professional Obligation and Law}

Military physicians and military health personnel have separate ethical obligation. The ethical sensitivity principles they possess by profession may seem to have lost their function in times of war or within armed forces strategies. They have various legal and medical obligations in regardless of their circumstances.

The definition of Health, which the World Health Organization (19) has not changed since 1948, refers not only to the absence of illness or disability, but to a complete state of physical, mental and social welfare. However, in the Universal Declaration of human rights published in 1948, the right to health within the framework of Social Security and the right to life is considered as the most fundamental right. In the 17th article of the 1982 Constitution (20), which is still valid in Turkish Law, the right to health is mentioned on the basis of the right to life. "Except for medical imperatives and cases written in the law, one's body integrity cannot be touched and subjected to scientific and medical experiments without their consent. Nobody can be tortured; nobody can be subjected to a penalty or treatment that is incompatible with human dignity."

The application of medical professions in Turkey is carried out with the "Law No. 1219 on the execution of the style of Tababet and Şuabati San'atlarının" (21). The regulation of medical deontology (22), published in 1960 and still valid in our country, also stated the rules that physicians and dentists should follow professionally. According to this regulation, the first task of physicians should be cared and respected for human health, life and personality without any discrimination based on religion, language and race.

There are many more examples of laws in the world and in our country. The main thing will be what to do in military and medical professions. Dr Tobin (23) defining the ethical dilemma of the military doctors serving in peace protecting operations states that; In World medicine organisation Habana Decleration on 1956 the medical ethics rules are defined to be the same either in peace or armed conflict time. When physicians have conflicting loyalties in performing their professional duties, their primary obligations to their patients are; Doctors in all their professional activities must comply with international conventions of human rights, international human law and World Medical Association Statements related to medical ethics (24).

According to the Regulations in Armed Conflict and Other Situations of Violence, which was last revised in the 63rd General Assembly of the World Medical Association in 2012; The main task of the medical profession is to protect health and save lives. Therefore, it is defined as not ethical prodecures for physicians to use scientific knowledge to destroy life, to weaken a person's physical or mental strength without therapeutic justification, to apply and recommend prophylactic, diagnostic or therapeutic procedures that are not necessary for the patient's health care, and to assist and participate in torture or inhuman treatment (24).

The Geneva Conventions and additional protocols, signed in 1949, originally prepared by Jean Henry Dunant, the founder of the International Red Cross Committee, formed the core of international humanitarian law studies that regulate the conduct of arme conflicts and limit their impact. These conventions protect those who are not involved in the war, such as healthcare personnel and civilians, and those who are no longer able to fight, and the patient prisoners of war. Each contract was created for a different group. With the first contract; injured and sick soldiers in ground wars, with the second contract; the soldiers on the ship that sank with the wounded and sick soldiers in naval wars, with the third contract; prisoners of war, with the fourth contract; the occupied civilians, hospitals and safe zones are protected (25).

The declaration of the World Medical Association (24) lists some of the conduct of physicians in armed conflict or other situations of violence as follows:

- He cannot leave sick and injured patients,

- He cannot act as an international violation.,

- He does not participate in any hostility and harmful action. 
- He does not discriminate against injuries and patients.

- He provides effective and impartial care while protecting injuries and patients. (without discrimination, including whether they are "enemies" or not),

- He should respect the will, trust and dignity of the injured / sick individual.

- He should not make any experimental attempts regarding the injured / patients without their real and valid consent in where they are deprived of freedom.

- He should take into account that women and children under armed conflict and violence have more and special health needs.

- He should respect the right of relatives to be informed about the status of the missing individual, where he is, and / or the status of health care.

- Even if he is convicted, he must provide health services to all.

- If does, he takes action to stop the distribution of unjust and inappropriate materials and drugs.

- He should be aware of the legal obligation to notify the authorities in case of any notifiable illness or trauma.

- He should do everything that he can to prevent retaliation against the injured/patients or healthcare.

\section{DISCUSSION}

Military persons fulfill their professional obligations according to the laws they are subject to. These obligations are carried out in a hierarchical system. The soldier of lower ranks are obliged to fulfill the orders given by the commanders and top ranks. In the code of absolute obedience, obeying the laws, regulations, the law of the subordinate and superior is considered the basis of military service. For the preservation and execution of this situation, punitive measures are applied by the specific laws. In armed conflict situations, criminal sanctions can be applied as much.

Although there are not many works written in this field, the military and autonomy section of the American Book of Military Medical Ethics states that soldiers should make a lot of individual sacrifices, including some autonomy. Most of the time, the soldier can exhibit behavior other than his own wishes. Personal liberties can sometimes be democratically constrained by the principle of harm, the legal moral principle, and the principle of paternalism. Proper balancing of individual autonomy with the needs of the military requires rigorous ethical analysis and justification. The limited autonomy in military service contrasts severely with civilian life (26).

Physicians perform the best practices for the good of their patients at all times and under all circumstances within the framework of deontological and legally regulated obligations. In accordance with the basic ethical principles of medicine, they approach their patients first with the principle that they should not harm and give benefits. They substitute these approaches according to the standards and experience of science. In their interventions to their patients, they may be exposed to malpractice cases in the troubles arising from the provision of all kinds of diagnosis, treatment and health services, starting with the application of triage.

In the beginning of the physician and soldier section of the book of Military Medical Ethics, showing an efforts to heal patients in backward conditions at brain surgery performed with limited medical supplies using flashlight during Japanese airstrikes may be a historical evidence of doctors. Medicine, a gateway to healing may exhibit a contrast image with military service, which offers death threats (27).

In addition to the above mentioned professional obligations, we need to evaluate a physician who practices best for the recovery of his patients and, a soldier who will harm the other person if necessary for national 
security. In the combination of military and physician identities, military physicians may face many ethical dilemmas in their duties and practices.

In medical interventions, it is a professional expectation that every physician should apply ethical rules and adhere to ethical principles. By profession, military physicians can sometimes be subordinate or superior. He may be superior to his subordinates while subordinate to his superior and may be forced to follow the instructions given. He may face a situation where national security is mandatory and he may be forced to engage in conduct that is inappropriate for medical ethics.

Military units which are unaware of the ethical dilemmas that their medical staff and doctors would experience in their practices, always feel lucky. Because they know that in the event of any injury, there is someone who will provide them with professional medical services. That is why the presence of a military doctor in a unit, always has a multiplier effect in comparing the forces possessed.

Medical support is provided within the armed forces with doctors and paramedics from the battalion to the smallest unit. The physicians in the auxiliary class who provide support services to the combatant classes are assigned to improve the combat personnel in all kinds of injury, disability and illness situations. The primary duty of a military physician is to provide support to the continuity of combat services with protecting the health of the soldiers. Besides medical deontology, it is aimed to protect the workforce that will benefit the union rather than be useful to the individual with military obligations. In the event of a soldier being injured, the demoralisation of other personnel in the combat area who witnessed the incident is assessed as much as the loss of that individual's health. A civilian doctor may not experience the dilemma of evaluating this situation, not only from the point of view of the patient, but also from the point of view of the unity and the consequences of the event that took place. The military doctor in the hierarchical system has to make decisions by evaluating not only the condition of the patient but also the condition of the unit.

We see that how complex a decision is to make regarding the situation of a military personnel. This can affect many people physically and emotionally, from personalle, the administration and medical staff even the family of patient soldier. Stress factors that the psychology of the soldiers involves, are the dynamics that should be taken into consideration with precision. Are these an ethical dilemma?

We can exemplify this situation with real stories from near Turkish history. Turkish Armed and other security forces have been facing a terror problem in southeastern Turkey and related conflicts in the last few decades. Low intensity warfare engagements causes wounding and causalities especially during summer season. In this conflict Armed Forces uses more effective small teams, consists of few professional soldiers, which have the ability to handle fast guerrilla warfare. These professional soldiers are well-trained, familiar with the region and experienced on such combat.

When a member of these Special Forces admitted to the clinic the best case scenario is the soldier's treatment with an emergency medical intervention and prescription. Yet, if the situation requires further care it is a much more complex and problematic process for the medical staff. For instance if the physician decides that the soldier needs to be hospitalized the team will miss that member for any mission during the treatment period.

In this case the physician will consider the success and security of the team and any possible criticizing from higher ranking combat officers besides the well-being of the soldier. The physician is facing a dilemma of either ignoring some needs of the patient that the treatment may require or causing the weakening of a combat team by cutting back a critical member which may cause further fatalities under severe combat conditions. Choosing a simple answer which is just following the medical procedure in this complex case will be both ignoring the special conditions of the warfare and the psychology of the physician who is a member of the armed forces. 
If we analyze the case from the point of the patient soldier we can see another dilemma. Hospitalization may protect her/him from a longer treatment and a further injury, yet s/he will feel the psychological burden of leaving the team members unsupported under critical conditions and a possible shame before his/her friends and commanders. However, if the soldier overlooks the initial injury and launches for a mission this may cause further injuries which will result longer absences or may face a decrease in combat skills because of feeling sick and unprepared.

Third dilemma occurs from the point of view of the team and troop commanders. Missing one key member in a team of few soldiers can be a very critical loss. Besides considering the health of the personnel the commanders would concern about the structure and functionality of the team. If the missing member is a very experienced and skilled soldier, his/her absence and substituting the position with a considerably newer member may result a dramatic decrease in the capability of the team. Moreover, if the missing member do not have strong relations with the entire team even a short absence may arise false opinions in the minds of some team members. Eventually this may greatly spoil the harmony and motivation of the team. While the commanders considering these facts they may override their limits in their relations with the medical team.

Another aspect of the dilemma is from the view point of the soldier's family. They are always proud of the service of their father/mother, yet they would never risk his/her life knowingly. By having a more emotional approach they may accuse the commanders to "sent a wounded soldier to death". Unknowingly they may shake the motivation of the soldier and the entire team.

Finally such a complex problem may develop that it emotionally and physically affects the soldier, the medical staff, the family, the combat team and the commanders. At this stage the psychology of the patient soldier and the causes of depression are the dynamics that should be under special consideration. While holding the patient health as the first priority any possible secondary benefit should not be permitted. At the same time the treatment stage should preserve feelings of attachment to the team and trust to the authorities. The physician should catch a good level of empathy to approach the soldier without passing the professional borders. The general rule of medicine which is "treating the patient instead of treating the sickness" is only applicable with special evaluation of the conditions surrounding the soldier. In short; the physician can only work through this special condition with an utmost cooperation with the commanders and team members and a great empathy with the soldier who has the feelings of "sacrificing his life" to preserve his/her health, motivation and attachment, but not allow any abuse.

Stress factors associated with the psychology of the sick soldier are dynamics that need to be considered in particular. While protecting patient health is the first priority, a possible secondary gain should not be allowed. As well as the sense of belonging of the soldier who is in the treatment stage, the sense of trust in his commanders and management should be maintained. The military physician should manage this complex situation well and take an empathetic approach without diverting to sympathy within professional boundaries.

The principle of "treating the patient, not the disease", which is an important rule in Medicine, will only be possible in this case with the physician's special assessment of the conditions in which the patient is present. The motivation and sense of belonging of this individual who carries both health anxiety and "risk his life" psychology, will be evaluated, and the physician will be able to know the patient well and make empathy in order not to challenge the abuse in the result of organized cooperation with the union commanders and other team personnel.

The basic duty of the physician is to treat the illness by using scientific knowledge. For this reason, it is accepted as the only individual that always creates a one-to-one relationship and looks for a solution to the problem of the physician. In medicine, the primary concern of the physician is to ensure the benefit of the patient (28). Similarly, it would be best for the military physician to make a decision after a detailed assessment. 
When we leave the situation and go back to the general public, Tobin (23) mentions the obligation of doctors to report the inhumane acts and abuses such as torture and slaughter as the first witnesses. Human Rights physicians, who believe in the magnitude of the impact of medical ethics on the protection of human rights, also recommend that military health professionals take steps to report violations of the Geneva Conventions (29). Cases of violence against physicians are not always requested, but they are also not evaluated in the first place. Another situation is that the physician of a union with inhuman behavior can report this situation very easily? Doctors may not be able to prevent international wars, but they can heal their wounds. Sometimes they can provide this physically and sometimes with reports.

London and his colleagues have written articles on human rights and Ethics in times of armed conflict as a double commitment of military health professionals. Although the physician-soldier role is seen as a natural moral impossibility in his articles, he states the necessity for the armed forces to have strictly military physicians to achieve success and securing the victory. Rather than a civilian physician, military physicians who know the army closely and play a role in missions, are a critical persons in carrying out missions (30).

Terrorist attacks and the technology that develops with each new war, can create new ethical problems in the military field and military medicine. Edmund (31) cites the ethical dilemmas seen and expressed in Military Medicine after the September 11 attacks: The treatment of captured terrorists during interrogation, the psychological care and suicide cases of imprisoned terrorists, the treatment of prisoners of war and the agents to be given to prisoners in unethical or illegal interrogation situations are just some of the ethical problems that military physicians will face. When resources are limited according to the principle of military medical triage, the idea of military doctors first intervening on soldiers who can return to the front line, and those whose treatment is delayed, is a separate ethical dilemma.

The debate about whether military physicians who have intervened in all the terrorist attacks in the world, serve in situations of armed conflict, even if for peacekeeping purposes, are first soldiers or physicians remains current. Annas has re-drawn attention to this issue in his "first, last, and always physician" article. Anna (32), biomedical science and technological developments in the United States National Bioethics Advisory Commission to advise the president on this issue is being discussed, and, except in case of necessity of medical ethics asserts that physicians should be the same for all. The real question in this case is whether there are necessity situations that require physicians to suspend their medical ethical obligations.

\section{CONCLUSION}

In the Modern age, wars are now conducted without human soldiers with computer and tecnologic weapons. However, human physicians are still intervening in those who are injured in their devastating impact. Physicians will always continue to be involved in the protection of human health and the provision of health services, whether as civilians or as soldiers everywhere.

It is a well-known fact that military physicians, one of the most important personnel of the military as a multiplier effect, will always encounter ethical elements in medical services given the nature of the physicianpatient relationship. To be able to be principled at the level of conduct and to apply ethical principles at the military medicine carries a distinct challenge within its own dynamics. The military physician's obligations to his patient, what he must do as a soldier and the demands of the military he is in could remain in a dilemma. He may not always perform ethical medical practices when he acts in accordance with the military laws and regulations he is subject to. It should be noted that the law does not always determine what is ethical. Only when behaved within the code of medical ethics can soldiers who have vowed to die to protect their homeland cause their national security efforts to be wasted. At this point, it is also important that military physicians know and recognize the ethical dilemmas they will be exposed to. 
Questioning the primacy of being a soldier or doctor is not a one-dimensional investigation. There is no simple answer for every situation. After a thorough analysis of each case one can reach a balanced approach. Each situation has unique characteristics that must be evaluated under its own circumstances. A more accurate approach may be possible with a balanced and broad analysis at all times

\section{References}

1. Arda B, Pelin SS. Tıbbi Etik; Tanımı, İçeriği, Yöntemi ve Başlıca Konuları. Ankara Tıp Mecmuası. 1995; (48):323336.

2. Büken, NÖ. Büken E. Nedir Şu “Tip Etiği” Dedikleri? Sürekli Tip Eğitimi Dergisi. 2002; (11):17-20.

3. Cevizci A. Felsefe terimleri sözlüğü. Paradigma Kitabevi, İstanbul. 2000.

4. Demirhan Erdemir A. Etik, Tıp Etiği, Tep Etiği İlkeleri Ve Hasta Hekim İlişkilerinde Etiğin Yeri. Erdem. 2005; 15(44): 27-72.

5. TDK. Güncel Sözlük. [Çevrimiçi]. 2020 [cited 2020 Ağustos 05]. Available from: https://sozluk.gov.tr/.

6. Kuçuradi İ. Etik ve Etikler. TMH-Türkiye Mühendislik Haberleri 2003;423:7-9.

7. Aristoteles. Nikomakhos’a Etik. Çeviri Eds. Akderin F. Say Yayınları, İstanbul, 2017; 41-46.

8. Beauchamp TL. Childress JF. editors. Principles of Biomedical Ethics, 7th ed. New York: Oxford University;2009. p. 1-3.

9. Aydın E. Tarihsel ve Güncel Yönden Tip Etiği. Erdem. 2005; 15(44): 83-102.

10. Yıldırım G, Kadığlu, S. Etik ve Tip Etiği Temel Kavramları. Cumhuriyet Üniversitesi Tip Fakültesi Dergisi. 2007;29(2): 7-12.

11. Civaner M. Sarıkaya Ö, Balcıoğlu, H. Uzmanlık Eğitiminde Tip Etiği. Anadolu Kardiyoloji Dergisi. 2009;9: 132-138.

12. Cevizci, A. Uygulamalı Etik. Say Yayınları, İstanbul, 2016; 50-52.

13. Çobanoğlu, N. Editorials, Klinikte Güncel Tıbbi Etik Sorunlar Özel Sayısı. Türkiye Klinikleri Tıp Etiği-HukukuTarihi-Özel Konular. 2015; 1(3).

14. Çobanoğlu, N. Kuramsal ve Uygulamalı Tip Etiği. Efil Yayınevi, Ankara, 2009; 22.

15. Noureddine S. Development of the ethical dimension in nursing theory. Int J Nurs Pract. 2001; 7(1):2-7.

16. Berggren I, Bégat I, Severinsson E. Australian clinical nurse supervisors' ethical decision-making style. Nurs Health Sci. 2002; 4(1-2):15-23.

17. Cerit Y. Hemşirelik Etik İkilem Testi'nin Geçerlik-Güvenirlik Çalışması ve Hemşirelerin Etik Karar Verebilme Düzeyi. Hacettepe Üniversitesi Hemşirelik Fakültesi Dergisi. 2010; 17(2): 47-67.

18. Williams, RJ. World Medical Assocition WMA, Medical Ethics Manual. Dünya tabipler BirliğiTip Etiği El kitabı. Çeviri Ed. Civaner M. Türk Tabipler Birliği, Ankara 2015.

19. WHO. World Health Organization. [Çevrimiçi], 1948 [cited 2020 Ağustos 06].. https://www.who.int/about/ who-we-are/frequently-asked-questions.

20. Anayasa, TC Anayasası. mevzuat. [Çevrimiçi] 1982. [cited 2020 Ağustos 06].https://www.mevzuat.gov.tr/ MevzuatMetin/1.5.2709.pdf.

21. 1219 sayılı Tababet Ve Şuabatı San’Atlarının Tarzı İcrasına Dair Kanun Değişiklik. Mevzuat. 6569 sayılı kanun. [Çevrimiçi] 1928. [cited 2020 Ağustos 06] https://www.mevzuat.gov.tr/MevzuatMetin/1.3.1219-20141119.pdf.

22. Resmi Gazete, Tibbi Deontoloji Nizamnamesi. 19 Şubat 1960 tarihli ve 10436 sayılı Resmi Gazete, 1960. [cited 2020 Ağustos 06] mevzuat.gov.tr.

23. Tobin J. The challenges and ethical dilemmas of a military medical officer serving with a peacekeeping operation in regard to the medical care of the local population. Journal of Medical Ethics 2005; 31:571-574.

24. World Medical Association WMA. Regulations in Times of Armed Conflict and Other Situations of Violence, revised by the 63rd WMA General Assembly, Bangkok, Thailand, October 2012. 
25. International Committee of the Red Cross, ICRC. Fourth Geneva convention. Geneva: ICRC, 1956. [Çevrimiçi] 1956 [cited 2020 Ağustos 06]. https:/www.icrc.org/en/document/geneva-conventions-1949-additionalprotocols.

26. Sandra, L. VISSER (Chapter 9 Ed.). Military Medical Etik, The Soldier And Autonomy. 1917;251-266.

27. Edmund, GH (Chapter 10 Ed.). Military Medical Ethics, Physıcıan-Soldier: A moral. Washington: yazarı bilinmiyor, 1917; 269-271.

28. Oğuz, NY. Klinik araştırmalarda etik sorunlar. Klinik Psikiyatri 1998;2:67-72.

29. Physicians for Human Rights, PHR. Physicians for Human Rights. [Çevrimiçi] 2020. [cited 2020 Ağustos 07]. https://phr.org/about/.

30. London L, Rubenstein LS, Baldwin-Ragaven L, Van Es A. Dual loyalty among military health professionals: human rights and ethics in times of armed conflict. Camb Q Healthc Ethics. 2006;15(4):381-391.

31. Howe EG. Dilemmas in Military Medical Ethics Since 9/11. Kennedy Institute of Ethics Journal 2003;13(2):175188.

32. Annas GJ. Military medical ethics-physician first, last, always. N Engl J Med 2008;359:1087-1090. 